\title{
COMPARATIVE EVALUATION OF PULPAL RESPONSE TO TRI-ANTIBIOTIC PASTE AND ALLIUM SATIVUM WITH FORMACRESOL AS PULPOTOMY MEDICATION IN PRIMARY TEETH:AN IN VIVO STUDY
}

\author{
Shaimaa M. Mahfouz ${ }^{*}$ and Omnya M. Wahba**
}

\begin{abstract}
Background:-To evaluate and compare Pulpal Response to Tri-antibiotic Paste and Allium Sativum with Formacresol as Pulpotomy Medication in Primary Teeth. Materials and Methods:-30 children in age group 7-9 years have bilateral primary teeth indicated for orthodontic serial extraction .children divided into two groups, (group I) included(15) children had bilateral primary teeth, the right side tooth treated with tri-antibiotic past (3 mix) (group IA) and left side tooth treated by formacresol (group IB) and (group II) included (15) children had bilateral primary teeth, the right side tooth treated with allium sativum oil (A. sativum) (group IIA) and left side tooth treated by formacresol (group IIB). Each tooth was treated with standard pulpotomy procedure. . Patients were recalled after 15 and 30 days' time interval as a part of orthodontic treatment. Teeth in each group were extracted and were subjected to decalcification procedure for histopathological evaluation. Results:- In group(I A) Nearly normal pulpal architecture was observed. Another finding common to all experimental groups was the presence of inflammatory processes of different levels of severity. Moderate amount of inflammatory cell infiltration was noted about 50-60\% in cases after 15 and 30 days. In addition the results of group (IB), (IIB) there was pulpal inflammation was prominently observed in all cases treated with formacresol. After 15 days about $33.3 \%$ of cases showed severe inflammation with lymphocytes and foamy macrophages while $66.6 \%$ showed moderate inflammatory infiltration. By the end of 14 days cases with severe pulpal inflammation were about $46.6 \%$. Also, in group (IIA) there was pulpal inflammation was prominently observed in all cases treated with formacresol. After 15 days about $33.3 \%$ of cases showed severe inflammation with lymphocytes and foamy macrophages while $66.6 \%$ showed moderate inflammatory infiltration. By the end of 30 days cases with severe pulpal inflammation were about $46.6 \%$.
\end{abstract}

Conclusion:- 1-Odontoblast remained vital in most cases treated with Both Tri-antibiotic paste and A. sativum . 2-Interal root resorption found in most specimens treated with formacresol .

Recommendations: Further clinical studies with long time evaluation periods should be done to investigate the effects of the three medicament on pulp tissues of primary teeth .

* Lecture Pediatric, Preventive and Dental Public Health , Faculty of Dentistry. Suez Canal University. ** Assistant Professor Oral Pathology Depatement, Faculty of Dentistry. Kafer Elshikh University. 


\section{INTRODUCTION}

Currently, there are altered methods and trials for the managing the vital pulp of primary teeth, this is according to extension of damage and the nature of pathologic condition for pulpal tissues ${ }^{(1)}$. Pulpotomy is a conservative technique used for removal of the infected coronal pulp tissue and preserve of the residual un-infected one with inert material ${ }^{(1,2)}$. A pulpotomy material should be bactericidal that is important for avoiding failures in the conservative endodontic treatment, spread of infection and further transferable of inflammatory processes to radicular pulp tissues ${ }^{(3)}$

Numerous pulpotomy materials were used for capping the radicular pulp, these include formocresol, glutaraldehyde, ${ }^{(4)}$ ferric sulfate, collagen material, and mineral trioxide aggregate ${ }^{(5)}$. Many estimated hazards of formocresol like; cytotoxicity, carcinogenicity, immunologic, biochemical, mutagenic, and teratogenic alterations in the host have been described. ${ }^{(6,7)}$ In addition, it produced enamel malformation in the permanent successors. ${ }^{(8)}$ On other hand, it was proved that the formocresol absorped systemically from treated tooth. ${ }^{(9)}$ Futhermore, The tissue damages were occurred in many internal organs, especially in kidney and liver, and the amount of formocresol in the blood was directly proportional to the number of formacresol treated teeth. ${ }^{(10)}$ Hence, increased utilization of indigenous plant medicines in developing countries became a policy of WHO in the 1970s. ${ }^{(11)}$

A need for natural medicament to substitute formocresol as a pulp dressing material comes to be vital. Generally, garlic has been used to treat many situations, including hypertension and many infectious diseases. It is used for reducing the cholesterol levels moreover, it has antineoplastic and antimicrobial effects. ${ }^{(12)}$

Idea of lesion sterilization and tissue repair (LSTR) by disinfection of dentinal, pulpal and periapical pathogens with application of antibacterial medication that results in healing and repair of tissues. Metronidazole is primarily bactericidal agent that has been used for this purpose $^{(13)}$. Certain bacteria resist metronidazole so; ciprofloxacin and minocycline were mixed with metronidazole to produce the $3 \mathrm{Mix}$ preparation ${ }^{(14)}$. Many trials proved the effectiveness of 3-mix as an oral bactericidal ${ }^{(15)}$, in addition it was used in primary teeth endodontic treatments ${ }^{(13,16)}$.

The bactericidal function of Allium sativum determined by allicin that is performed by the enzymatic activity of allinase (a cysteine sulfoxide lyase). ${ }^{(17)}$ Garlic has been prevent growth of several gram-positive and gram-negative bacteria. ${ }^{(18)}$. Allium sativum extract has been effected on numerous pathogenic bacteria, viruses, and fungi also, garlic extract has bactericidal action on multidrugresistant (MDR) strains of Streptococcus mutans that was found in human carious teeth. ${ }^{(19)}$

The present in vivo study was undertaken to evaluate and compare the pulp response of triantibiotic paste and Allium sativum with formacresol as pulptomy medication in primary teeth.

\section{Ethics:}

The present study was approved from the Research Ethics Committee, Faculty of Dentistry, Suez Canal University code (198/2019).

\section{MATERIALS AND METHODS}

A randomized, controlled prospective clinical study was done at Pediatric Dentistry Department Outpatient clinic, Suez Canal University after obtaining an informed written consent from parents. A sample of 60 teeth from 30 children in age group 7-9 years have bilateral primary teeth which needed dental treatment due to deep caries and had at least two third of the root indicated for orthodontic serial extraction ( confirmed by periapical $\mathrm{x}$ ray). Children divided into two groups, (group I) included(15) children had bilateral primary teeth, 
the right side tooth treated with tri-antibiotic past (3 mix) (group IA) and left side tooth treated by formacresol* (group IB) and (group II ) included (15) children had bilateral primary teeth, the right side tooth treated with allium sativum oil** (A. sativum) (group IIA) and left side tooth treated by formacresol (group IIB) . Each tooth was treated with standard pulpotomy procedure.

\section{Inclusion criteria}

- Healthy \& cooperative child

- No previous history of taking antibiotic therapy for at least 2 weeks before operative procedure.

- No history of spontaneous pain

- No pathologic tooth mobility

- Normal gingival and periodontal condition

- Absence of furcal/periapical radiolucency (1)

\section{Technique}

Clinical and radiographic examinations were performed for each tooth before treatment. Teeth were anesthetized using Mepecaine -L.A (local anesthetic solution containing $20 \mathrm{mg}$ Mepivacaine hydrochloride . Rubber dam and high suction were used in pulpotomy procedure. Cavity outline was performed by sterile \#330 high speed bur using water spray. Caries was removed by large spoon excavator. When pulpal exposure was occurred, the roof of pulp chamber removed by low speed round bur.

Hemostasis was achieved by applying pressure with moist cotton pellet with saline. If bleeding did not stopped within 5 min, tooth was excluded from study. Then the test materials were applied as follow:-Tri-antibiotic paste (IA):- ${ }^{(15)}$ Teeth in this group treated with freshly prepared mix of triantibiotic that was prepared as follow: a mixture of metronidazole***, ciprofloxacin**** and minocycline $* * * * *$.

The drugs are ground into fine powder using sterilized mortar pestle. The powered drugs were kept separately in amber-colored airtight containers. The fine powder was used up within a month. 3Mix paste was freshly prepared for each use. The same amount of each powdered drug (1:1:1) was mixed to form modified 3Mix powder. One part of propylene glycol (P) and the same volume of macrogol (M) were mixed to make (3 mix ) paste.

-A.sativum group (II A): (15) teeth treated with freshly prepared mix of zinc oxide powder with one drop of allium sativum oil till reach suitable consistency (1:1 ratio by volume) to cover pulp stumps.-Formcresol groups (IB) and (IIB):(30) Teeth treated by using sterile cotton pledget with formcresol for 3-5 min then, removed. Then pulp stumps were dressed with thick paste prepared by mixing zinc oxide****** powder with one drop of eugenol. Then all treated teeth were restored with glass ionomer cement*******. Patients were recalled after 15 and 30 days' time interval as a part of orthodontic treatment. Seven teeth from group (IA), Seven teeth from group (IIA) and (15) teeth from formacresol treated groups teeth were extracted after 15 days and then subjected to decalcification procedure. Eight teeth from group (IA), Eight teeth from group (IIA) and the other (15) teeth from formacresol treated groups

\footnotetext{
* Prevest-dentopro dental

** El Captin Company

*** Flagyl Avents

**** Ciprobay Bayer

****** Minocin Lederale

******** Meta Biomed

********* Medfill Promedica
} 
were extracted after 30 days and then subjected to decalcification procedure.

Tissue fixation, decalcification, processing and paraffin embedding

For decalcified histology, all teeth were decalcified sequentially in $20 \%$ EDTA at $4{ }^{\circ} \mathrm{C}$ for approximately 5 weeks, until flexible by manual testing. The specimens then were routinely processed and embedded in paraffin. Serial sections were cut at $5 \mu \mathrm{m}$ thickness. Deparaffinize the sections by 2 changes of xylene for 10 minutes each. Re-hydrate in 2 changes of absolute alcohol, 5 minutes each. 95\% alcohol for 2 minutes and $70 \%$ alcohol for 2 miuntes. Wash briefly in distilled water. Stain in Harris hematoxylin solution for 8 minutes. Wash in running tap water for 5 minutes. Differentiate in $1 \%$ acid alcohol for 30 seconds. Wash running tap water for 1 minute. Bluing in $0.2 \%$ ammonia water or saturated lithium carbonate solution for 30 seconds to 1 minute. Wash in running tap water for 5 minutes. Rinse in 95\% alcohol, 10 dips. Counterstain in eosin-phloxine solution for 30 seconds to 1 minute. Dehydrate through 95\% alcohol, 2 changes of absolute alcohol, 5 minutes each. Clear in 2 changes of xylene, 5 minutes each. Mount with xylene based mounting medium for for conventional histological assessment using light microscope (Leica ICC50 HD). 20

\section{Statistical analysis}

The data were analyzed using version 20 of the SPSS. Qualitative data were compared using chi-squared statistics. Quantitative data were summarized using mean, standard deviation, and confidence interval and compared using Student's test and/or one way analysis of variance test. All $\mathrm{P}$ values were determined, and statistical significance was based on a $\mathrm{P}$ value of 0.05 .

\section{RESULTS}

The sections were blindly evaluated by a histopathologist using the following criteria as indicated in Tables 1 to 8 .

TABLE (1): Degree of pulpal inflammation

\begin{tabular}{|c|c|}
\hline Score & Description \\
\hline $\mathbf{0}$ & No inflammation \\
\hline $\mathbf{1}$ & Mild inflammation \\
\hline $\mathbf{2}$ & Moderate inflammation \\
\hline $\mathbf{3}$ & Severe inflammation \\
\hline
\end{tabular}

TABLE (2): Degree of pulpal vascularity

\begin{tabular}{|c|c|}
\hline Score & Description \\
\hline $\mathbf{1}$ & Mild vascularity \\
\hline $\mathbf{2}$ & Moderate vascularity \\
\hline $\mathbf{3}$ & Severe vascularity \\
\hline
\end{tabular}

TABLE (3): Degree of pulpal fibrosis

\begin{tabular}{|c|c|}
\hline Score & Description \\
\hline $\mathbf{0}$ & No fibrosis \\
\hline $\mathbf{1}$ & Mild fibrosis \\
\hline $\mathbf{2}$ & Moderate fibrosis \\
\hline
\end{tabular}

TABLE (4): Quality of odontoblastic layer

\begin{tabular}{|c|c|}
\hline Score & Description \\
\hline $\mathbf{1}$ & Organized layer \\
\hline $\mathbf{2}$ & Non-organized layer \\
\hline
\end{tabular}


TABLE (5): Internal root resorption

\begin{tabular}{|c|c|}
\hline Score & Description \\
\hline $\mathbf{0}$ & No resorption \\
\hline $\mathbf{1}$ & Presence of resorption \\
\hline
\end{tabular}

TABLE (6): Presence of calcified structure in root canal

\begin{tabular}{|c|c|}
\hline Score & Description \\
\hline $\mathbf{0}$ & No calcified structures \\
\hline $\mathbf{1}$ & Presence of calcified structures \\
\hline
\end{tabular}

TABLE (7): Presence of necrosis in root canal

\begin{tabular}{|c|c|}
\hline Score & Description \\
\hline $\mathbf{0}$ & No necrosis \\
\hline $\mathbf{1}$ & Presence of necrosis \\
\hline
\end{tabular}

TABLE (8): Presence of dentin chips

\begin{tabular}{|c|c|}
\hline Score & Description \\
\hline $\mathbf{0}$ & No dentin chips \\
\hline $\mathbf{1}$ & Presence of dentin chips \\
\hline
\end{tabular}

\section{Histological evaluation}

\section{In Formocresol group}

Pulpal inflammation was prominently observed in all cases treated with formacresol. After 15 days about $33.3 \%$ of cases showed severe inflammation with lymphocytes and foamy macrophages while $66.6 \%$ showed moderate inflammatory infiltration. By the end of 30 days cases with severe pulpal inflammation were about $46.6 \%$. With formacresol treatment, pulpal vascularity varied from mild to moderate. After 15 days, $90 \%$ were mild, $10 \%$ were moderate but after 30 days, mild cases were $80 \%$ and $20 \%$ showed moderate pulpal vascularity. Formation of collagen fibers was observed obviously. After 15 days, cases showed mild, moderate and severe fibrosis in pulp tissue 6.6, 33.3 and $60 \%$ respectively. But by the end of 30 days, cases showed mild, moderate and severe fibrosis in pulp tissue 6.6, 53.3 and $40 \%$ respectively. Odontoblastic layer was not intact throughout the dentine pulp complex. Ranging from $66.6 \%$ to 83.3 $\%$ of cases showed disorganized odontoblastic layer after 15 and 30 days respectively (fig 1). Internal root resorption is the result of odontoclastic activity due to the precipitating factor as vascular changes in the pulp, inflammatory infiltration and formation of granulation tissue. Root resorption occurs in $66.6 \%$ and $80 \%$ of cases after 15 and 30 days respectively. Pulp stones were isolated and scattered after 15 days (60\%) and after 30 days (73.3\%). The resulting necrosis may have been due to excess formocresol in the cotton, which must have leaked and permeated into the surrounding tissue. Necrosis either partial or complete was noted in about $66.6 \%$ of cases. There was no reparative dentin formation in any area except in few cases (10\%) showed fragments of dentin ships (fig 1, table 9).

\section{In Tri antibiotic paste (TAP) group}

Nearly normal pulpal architecture was observed. Another finding common to all experimental groups was the presence of inflammatory processes of different levels of severity. Moderate amount of inflammatory cell infiltration was noted about 50$60 \%$ in cases after 15 and 30 days. Blood vessels were prominent in most cases and pulp vascularity varied from moderate to severe. After 15days, $66.6 \%$ of cases showed moderate pulp vascularity while $33.3 \%$ showed severe. At the end of 30 days, the results were $53.3 \%$ moderate and $46.6 \%$ severe. The production of fibrous tissue was a prominent feature. The pulpal exposure sites were completely obstructed with more fibrous tissue formation 
underlined by greater area of collagen hyalinization. The results were about (50-60\% moderate, $50-40 \%$ severe). Nearly $70 \%$ of cases showed organized odontoblastic layer (fig 2).

In all cases of the study, only $26.6 \%$ of cases showed internal root resorption at the end of 30 days. Small pulp stones were observed in $33.3 \%$ of cases and $46.6 \%$ after 15 and 30 days respectively. Small area of necrosis (13-20\%) of cases was noted. Regarding amount of hard tissue formation, dispersed dentin particles were visible about $20 \%$ of cases (fig 2, table 9).

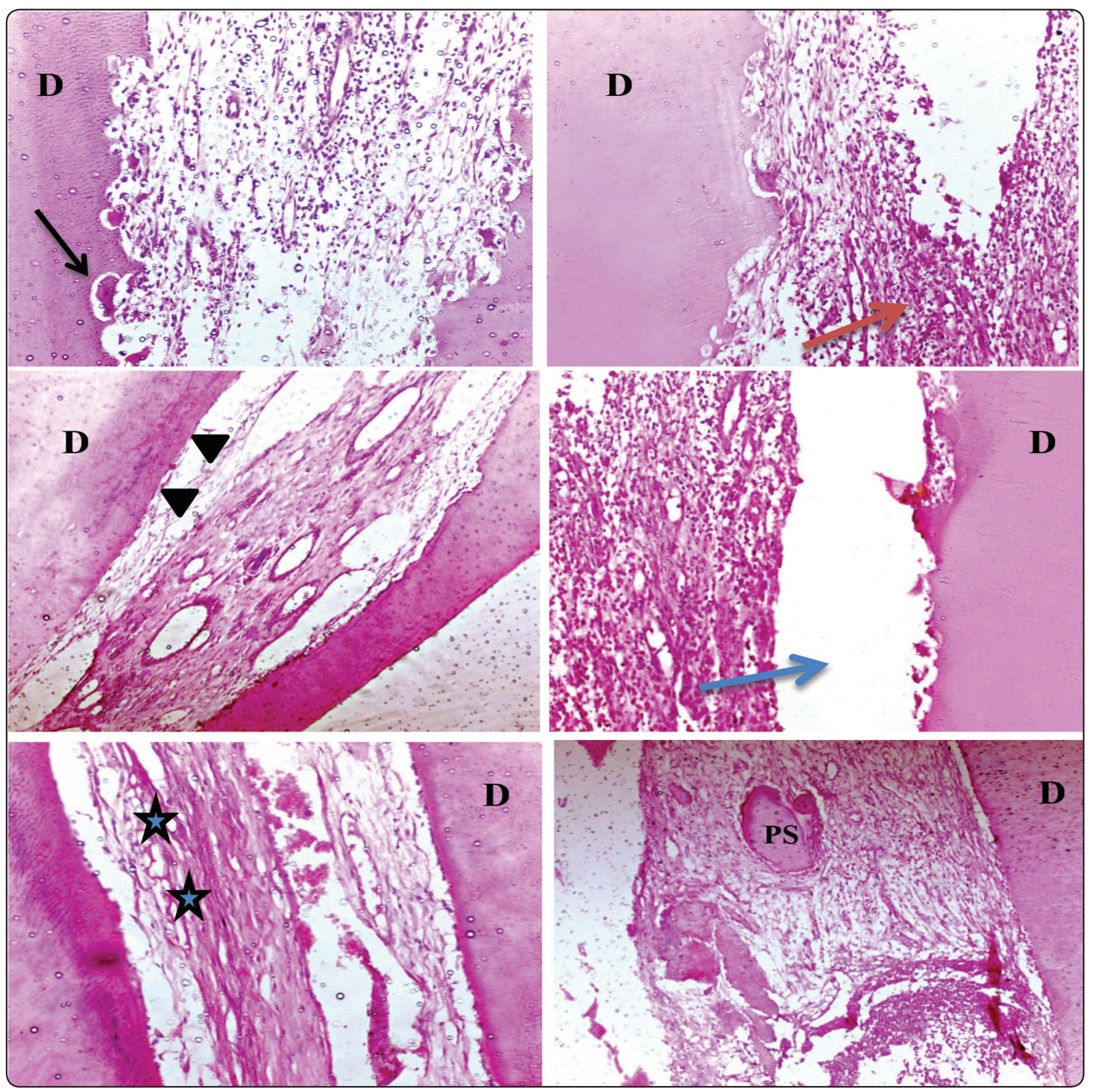

Fig. (1) Representative decalcified section of cases treated with formocresol showing (D) Dentin (PS) Pulp Stone, (black arrow) area of internal root resorption, (red arrow) pulpal inflammation, (arrow heads) disorganized odontoblastic layer, (blue arrow) area of necrosis, (Stars) area of pulp fibrosis. $\{\mathrm{H}$ and E x 200\} 


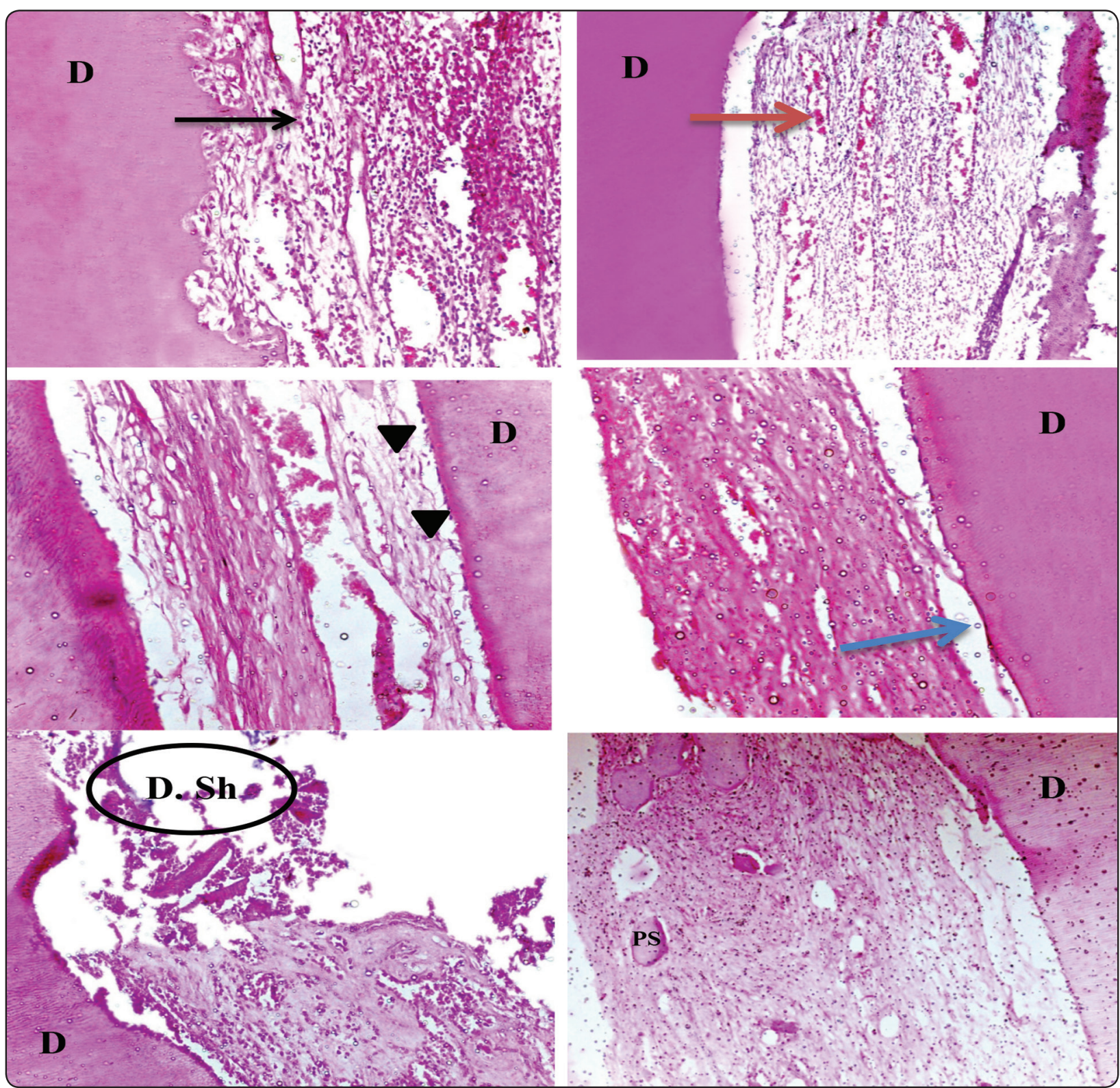

Fig. (2) Representative decalcified section of cases treated with Tri antibiotic paste (TAP) showing (D) Dentin, (PS) Pulp Stone, (D.Sh) dentin ships, (black arrow) area of pulpal inflammation, (red arrow) pulpal vasculature, (arrow heads) disorganized odontoblastic layer, (blue arrow) small area of necrosis. $\{\mathrm{H}$ and $\mathrm{E}$ x 200\}.

\section{In Allium Sativum group}

Mild pulpal inflammation was observed in 80 $\%$ of cases treated with Allium Sativum at the end of 30 days. Blood vessels were noted in all cases of Allium Sativum. After 30 days, about $86.6 \%$ of cases showed moderate vascularity of pulp tissue, $6.6 \%$ of cases mild and $6.6 \%$ of cases showed severe vascularity. Presence of collagen fibers were noted as dispersed fibers not well formed collagen bundles. About $80 \%$ of cases showed mild pulpal fibrosis after 30 days. The odontoblastic layer was well organized in about $73 \%$ of cases treated with Allium Sativum (fig 3).

Internal root resorption was not a common feature that observed in case of Allium Sativum. Only $20 \%$ of cases showed a small focus of internal root resorption. Calcified pulp stones were rarely found in the pulp. At the end of 30 days, less than $15 \%$ of 


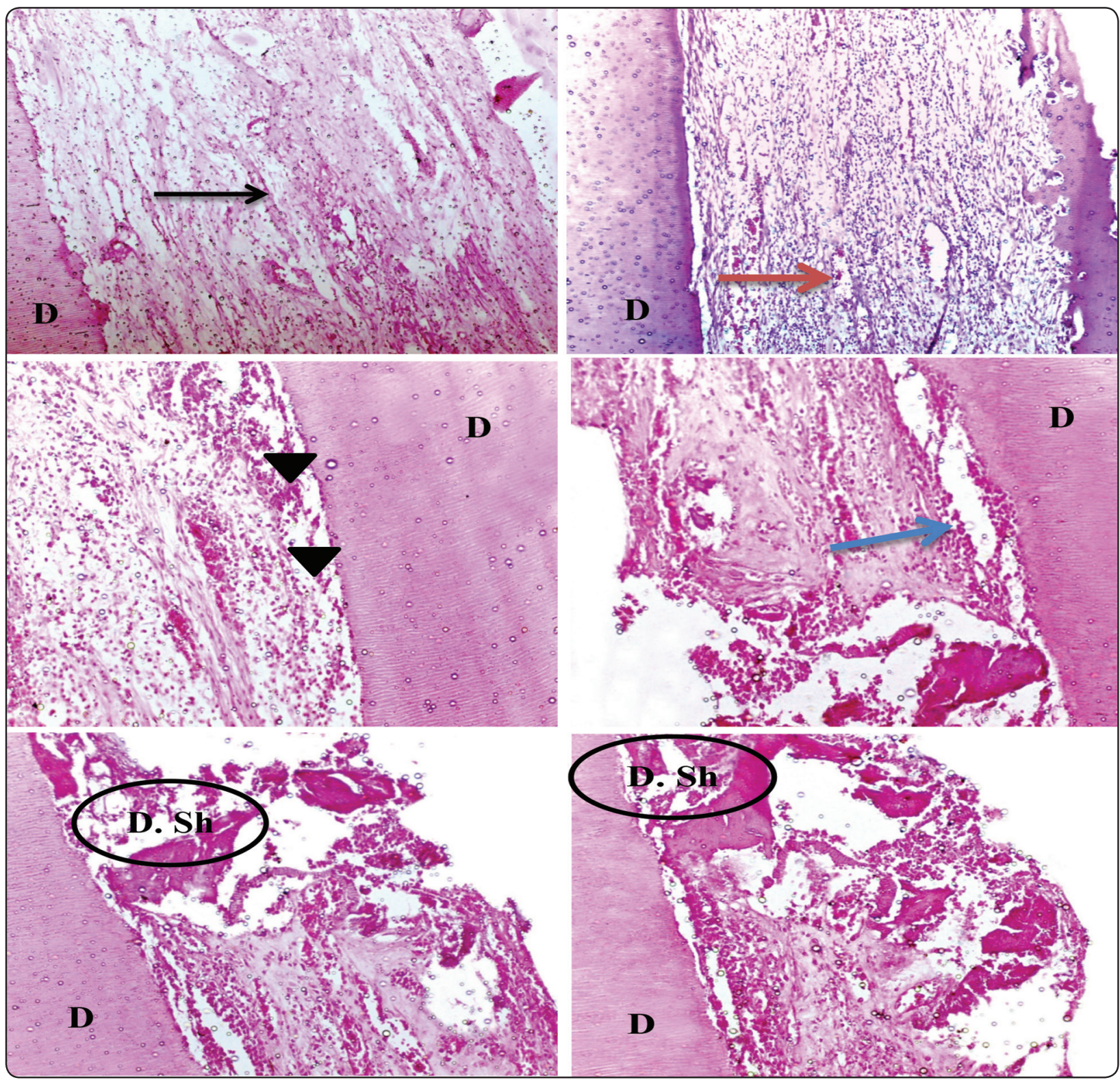

Fig. (3) Representative decalcified section of cases treated with Allium Sativum showing (D) Dentin, , (D.Sh) dentin ships, (black arrow) small area of pulpal inflammation, (red arrow) pulpal vasculature, (arrow heads) odontoblastic layer, (blue arrow) small area of necrosis. $\{\mathrm{H}$ and $\mathrm{E} \times 200$, last picture $\mathrm{x} 400\}$.

cases showed scattered pulp stones. About 10\% of all cases treated with Allium Sativum showed areas of necrosis after 30 days. Fragments of dentin were noted in about $33.3 \%$ of cases treated with Allium Sativum at the end of 30 days (fig 3, table 9).

According to the results of the study, degree of pulpal inflammation, vascularity and fibrosis were significant between groups treated with formocresol, triantibiotic paste and allium sativum
( $\mathrm{p}$ value $=0.001)$. Results of destruction of odontoblastic layer were significant only between formocresol and allium sativum $(p=0.027)$. But there was no significant correlation in quality of odontoblastic layer between triantibiotic paste and allium sativum $(p=0.7)$. Internal root resorption, presence of pulp stones and necrosis results showed also significant correlation $(\mathrm{p}=0.001, \mathrm{p}=0.012, \mathrm{p}$ $=0.05$ respectively) (table 10$)$. 
TABLE (9): Results of Formocresol, Triantibiotic paste and Allium Sativum groups

\begin{tabular}{|c|c|c|c|c|c|c|}
\hline & \multicolumn{2}{|c|}{$F^{*}(\mathbf{n}=30)$} & \multicolumn{2}{|c|}{ TAP** $(\mathbf{n}=15)$} & \multicolumn{2}{|c|}{$\operatorname{AS}^{* * * *}(\mathbf{n}=15)$} \\
\hline & 15 days & 30 days & 15 days & 30 days & 15 days & 30days \\
\hline 1.Pulpal inflammation & $\begin{array}{l}10 \text { moderate } \\
5 \text { severe }\end{array}$ & $\begin{array}{l}8 \text { moderate } \\
7 \text { severe }\end{array}$ & $\begin{array}{l}3 \text { mild } \\
4 \text { moderate }\end{array}$ & $\begin{array}{l}3 \text { mild } \\
5 \text { moderate }\end{array}$ & 7 mild & $\begin{array}{l}1 \text {-ve } \\
7 \text { mild }\end{array}$ \\
\hline 2.Pulpal vascularity & $\begin{array}{l}13 \text { mild } \\
2 \text { moderate }\end{array}$ & $\begin{array}{l}12 \text { mild } \\
3 \text { moderate }\end{array}$ & $\begin{array}{l}6 \text { moderate } \\
1 \text { severe }\end{array}$ & $\begin{array}{l}5 \text { moderate } \\
3 \text { severe }\end{array}$ & $\begin{array}{l}3 \text { mild } \\
4 \text { severe }\end{array}$ & $\begin{array}{l}1 \text { mild } \\
6 \text { moderate } \\
1 \text { severe }\end{array}$ \\
\hline 3. Pulpal fibrosis & $\begin{array}{l}1 \text { mild } \\
8 \text { moderate } \\
6 \text { severe }\end{array}$ & $\begin{array}{l}1 \text { mild } \\
8 \text { moderate } \\
6 \text { severe }\end{array}$ & $\begin{array}{l}5 \text { moderate } \\
2 \text { severe }\end{array}$ & $\begin{array}{l}5 \text { moderate } \\
3 \text { severe }\end{array}$ & $\begin{array}{l}6 \text { mild } \\
1 \text { moderate }\end{array}$ & $\begin{array}{l}5 \text { mild } \\
3 \text { moderate }\end{array}$ \\
\hline 4. Odontoblastic layer & $\begin{array}{l}5 \text { intact } \\
10 \text { not intact }\end{array}$ & $\begin{array}{l}2 \text { intact } \\
13 \text { not intact }\end{array}$ & $\begin{array}{l}5 \text { intact } \\
2 \text { not intact }\end{array}$ & $\begin{array}{l}5 \text { intact } \\
3 \text { not intact }\end{array}$ & $\begin{array}{l}5 \text { intact } \\
2 \text { not intact }\end{array}$ & $\begin{array}{l}6 \text { intact } \\
2 \text { not intact }\end{array}$ \\
\hline 5.Internal root resorption & $\begin{array}{l}5-\mathrm{ve} \\
10+\mathrm{ve}\end{array}$ & $\begin{array}{l}2-v e \\
13+v e\end{array}$ & $\begin{array}{l}6-\mathrm{ve} \\
1+\mathrm{ve}\end{array}$ & $\begin{array}{l}5-\mathrm{ve} \\
3+\mathrm{ve}\end{array}$ & $\begin{array}{l}5 \text {-ve } \\
2+\text { ve }\end{array}$ & $\begin{array}{l}6 \text {-ve } \\
2+v e\end{array}$ \\
\hline 6. Pulp stones & $\begin{array}{l}6-\mathrm{ve} \\
9+\mathrm{ve}\end{array}$ & $\begin{array}{l}3 \text {-ve } \\
12+\mathrm{ve}\end{array}$ & $\begin{array}{l}6-\mathrm{ve} \\
1+\mathrm{ve}\end{array}$ & $\begin{array}{l}5-\mathrm{ve} \\
3+\mathrm{ve}\end{array}$ & $\begin{array}{l}5 \text {-ve } \\
2+\text { ve }\end{array}$ & $\begin{array}{l}5 \text {-ve } \\
3+v e\end{array}$ \\
\hline 7.Necrosis & $\begin{array}{l}5-\mathrm{ve} \\
10+\mathrm{ve}\end{array}$ & $\begin{array}{l}5-\mathrm{ve} \\
10+\mathrm{ve}\end{array}$ & $\begin{array}{l}5-\mathrm{ve} \\
2+\mathrm{ve}\end{array}$ & $\begin{array}{l}5-v e \\
3+v e\end{array}$ & $\begin{array}{l}5 \text {-ve } \\
2+\text { ve }\end{array}$ & $\begin{array}{l}6 \text {-ve } \\
2+\mathrm{ve}\end{array}$ \\
\hline 8. Dentin ships & $\begin{array}{l}12-v e \\
3+v e\end{array}$ & $\begin{array}{l}11-\mathrm{ve} \\
4+\mathrm{ve}\end{array}$ & $\begin{array}{l}6-\mathrm{ve} \\
1+\mathrm{ve}\end{array}$ & $\begin{array}{l}5-\mathrm{ve} \\
3+\mathrm{ve}\end{array}$ & $\begin{array}{l}5 \text {-ve } \\
2+v e\end{array}$ & $\begin{array}{l}6 \text {-ve } \\
2+\mathrm{ve}\end{array}$ \\
\hline
\end{tabular}

TABLE (10): Correlation between Formocresol, Triantibiotic paste and Allium Sativum groups

\begin{tabular}{|c|c|c|c|c|c|c|c|c|c|c|c|}
\hline \multirow{4}{*}{$\begin{array}{c}\text { 1.Pulpal } \\
\text { inflammation }\end{array}$} & & \multicolumn{3}{|c|}{ Range } & \multirow{2}{*}{$\begin{array}{c}\text { Mean } \\
2.53\end{array}$} & \multirow{2}{*}{$\begin{array}{l} \pm \\
\pm\end{array}$} & \multirow{2}{*}{$\frac{\text { S. D }}{0.52}$} & \multirow{4}{*}{$\begin{array}{l}\text { F. test } \\
39.723\end{array}$} & \multirow{4}{*}{$\begin{array}{l}\text { p. value } \\
0.001 *\end{array}$} & \multirow[b]{2}{*}{ P1 } & \multirow[b]{2}{*}{$0.001 *$} \\
\hline & $\mathbf{F}$ & 2 & - & 3 & & & & & & & \\
\hline & TAP & 1 & - & 2 & 1.60 & \pm & 0.51 & & & $\mathrm{P} 2$ & $0.001 *$ \\
\hline & AS & 0 & - & 2 & 0.87 & \pm & 0.52 & & & P3 & $0.001 *$ \\
\hline \multirow{3}{*}{$\begin{array}{c}\text { 2.Pulpal } \\
\text { vascularity }\end{array}$} & $\mathbf{F}$ & 1 & - & 2 & 1.20 & \pm & 0.41 & \multirow{3}{*}{31.787} & \multirow{3}{*}{$0.001 *$} & $\mathrm{P} 1$ & $0.001 *$ \\
\hline & TAP & 2 & - & 3 & 2.47 & \pm & 0.52 & & & $\mathrm{P} 2$ & $0.001 *$ \\
\hline & AS & 1 & - & 3 & 2.00 & \pm & 0.38 & & & P3 & $0.006^{*}$ \\
\hline \multirow{3}{*}{$\begin{array}{l}\text { 3. Pulpal } \\
\text { fibrosis }\end{array}$} & $\mathbf{F}$ & 1 & - & 3 & 2.33 & \pm & 0.62 & \multirow{3}{*}{26.616} & \multirow{3}{*}{$0.001 *$} & P1 & 0.489 \\
\hline & TAP & 2 & - & 3 & 2.47 & \pm & 0.52 & & & $\mathrm{P} 2$ & $0.001 *$ \\
\hline & $\mathbf{A S}$ & 1 & - & 2 & 1.20 & \pm & 0.41 & & & P3 & $0.001 *$ \\
\hline \multirow{3}{*}{$\begin{array}{l}\text { 4. Odonto- } \\
\text { blastic layer }\end{array}$} & $\mathbf{F}$ & 1 & - & 2 & 1.67 & \pm & 0.49 & \multirow{3}{*}{3.014} & \multirow{3}{*}{0.060} & P1 & 0.063 \\
\hline & TAP & 1 & - & 2 & 1.33 & \pm & 0.49 & & & $\mathrm{P} 2$ & $0.027 *$ \\
\hline & $\mathbf{A S}$ & 1 & - & 2 & 1.27 & \pm & 0.46 & & & P3 & 0.704 \\
\hline \multirow{3}{*}{$\begin{array}{c}\text { 5. Internal } \\
\text { root resorption }\end{array}$} & $\mathbf{F}$ & 0 & - & 1 & 0.80 & \pm & 0.41 & \multirow{3}{*}{11.094} & \multirow{3}{*}{$0.001 *$} & $\mathrm{P} 1$ & $0.001 *$ \\
\hline & TAP & 0 & - & 1 & 0.27 & \pm & 0.46 & & & $\mathrm{P} 2$ & $0.001 *$ \\
\hline & $\mathbf{A S}$ & 0 & - & 1 & 0.13 & \pm & 0.35 & & & $\mathrm{P} 3$ & 0.378 \\
\hline \multirow{3}{*}{ 6.Pulp stones } & $\mathbf{F}$ & 0 & - & 1 & 0.73 & \pm & 0.46 & \multirow{3}{*}{4.941} & \multirow{3}{*}{$0.012 *$} & P1 & 0.123 \\
\hline & TAP & 0 & - & 1 & 0.47 & \pm & 0.52 & & & $\mathrm{P} 2$ & $0.003 *$ \\
\hline & $\mathbf{A S}$ & 0 & - & 1 & 0.20 & \pm & 0.41 & & & $\mathrm{P} 3$ & 0.123 \\
\hline \multirow{3}{*}{ 7.Necrosis } & $\mathbf{F}$ & 0 & - & 1 & 0.67 & \pm & 0.49 & \multirow{3}{*}{6.067} & \multirow{3}{*}{$0.005 *$} & P1 & $0.016^{*}$ \\
\hline & TAP & 0 & - & 1 & 0.27 & \pm & 0.46 & & & $\mathrm{P} 2$ & $0.002 *$ \\
\hline & $\mathbf{A S}$ & 0 & - & 1 & 0.13 & \pm & 0.35 & & & P3 & 0.408 \\
\hline \multirow{3}{*}{$\begin{array}{l}\text { 8. Dentin } \\
\text { ships }\end{array}$} & $\mathbf{F}$ & 0 & - & 1 & 0.13 & \pm & 0.35 & \multirow{3}{*}{0.817} & \multirow{3}{*}{0.449} & P1 & 0.408 \\
\hline & TAP & 0 & - & 1 & 0.27 & \pm & 0.46 & & & $\mathrm{P} 2$ & 0.216 \\
\hline & $\mathbf{A S}$ & 0 & - & 1 & 0.33 & \pm & 0.49 & & & P3 & 0.678 \\
\hline
\end{tabular}




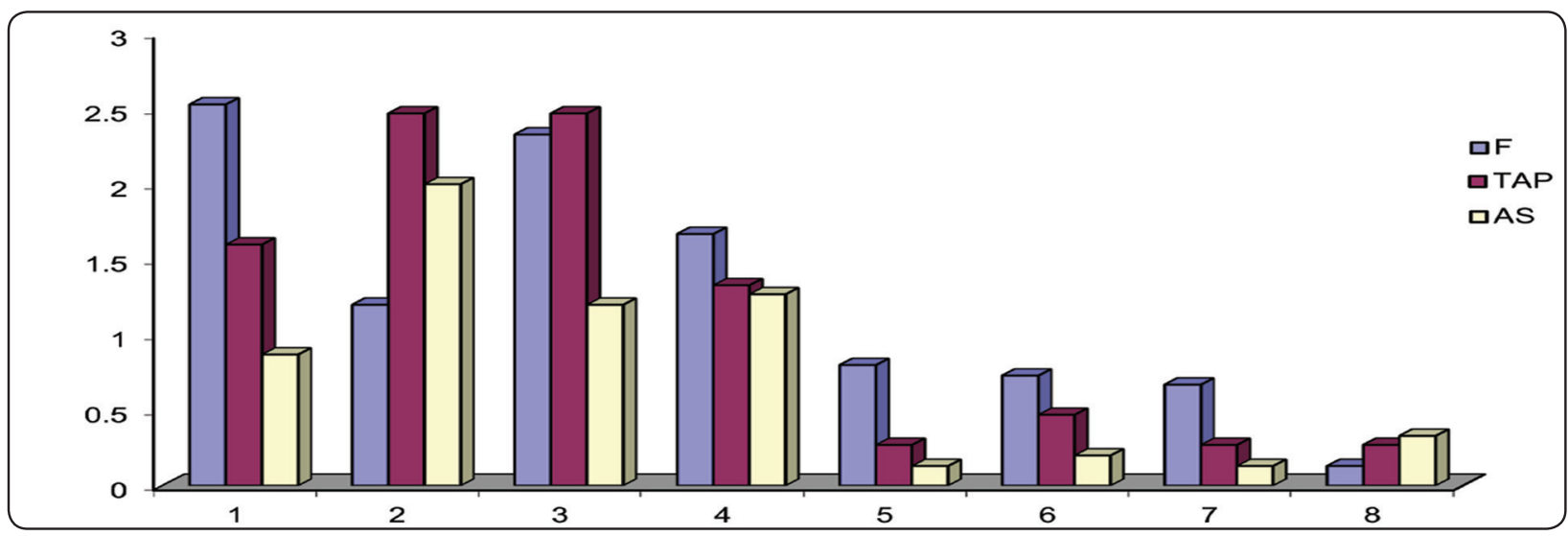

Fig 4: Correlation between Formocresol, Triantibiotic paste and Allium Sativum groups

\section{DISCUSSION}

Clinical and radiographic evaluations of pulpotomies using mixture of three antibiotics have been estimated in numerous studies ${ }^{(20)}$. Also, the effect of Allium sativum has been evaluated clinically and radiographically as pulpotomy medicament ${ }^{(21)}$. Studying the histologic response of pulp to mixture of three antibiotic and Allium sativum gives a better insight into their mechanisms of action and still are the most relevant .Until now, this study is the first one that histologically compare the effects of Formcresol, mixture of three antibiotic and Allium sativum on vital pulp tissues in primary teeth invivo thus it can be considered a preliminary study.

The follow up periods of current study are limited to 15 and 30 days to evaluate the inflammatory responses of tested materials on vital pulp tissues which may be enough for this purpose. This disagree with Kakarla et al ${ }^{(22)}$, who extracted primary teeth after one week and two weeks to histologically study the dental pulp response to collagen and pulpotec as pulpotomy agents. In addition, this disagrees with Sivadas ${ }^{(23)}$ et al., who evaluate and compare the pulp response of primary teeth in vitro to ferric sulphate and diode laser as pulpotomy agents at 4 weeks and at 6 weeks.

This study was a single blind in vivo study, where the oral pathologist was blind to not af- fecting on histopathologial results in agreement with Ratnakumari and Thomas ${ }^{(24)}$ and Sivadas et al., ${ }^{(23)}$. Formacresol used in this study as pulpotomy material as a gold stander agent for this technique. This is inconsistent with Ratnakumari and Thomas ${ }^{(24)}$ who used formacresol as a positive control group.

The results of current study revealed that there was moderate to sever inflammation in formacresol treated group and presence of sever pulpal fibrosis.These findings are in agreement with Omar et al., ${ }^{(25)}$. Moreover, there was internal root resorption in formacresol group and there were partial and complete necrosis in $66.6 \%$ of cases because it increases the inflammation of pulp tissues and formations of abscess ${ }^{(26)}$. Reaction to formacresol may be attributed to numerous causes; trauma during removal of pulp tissues or cytotoxicity of materials ${ }^{(27)}$.

On other hand, specimens treated with 3 mix showed mild to moderate pulpal inflammation about $50-60 \%$ of cases after 15 days and 30 days also, moderate to severe increasing in pulpal vascularity with greater infiltration of fibrous tissues specially collagen fibers that is attributed to disinfection of tissues which led to repair of damaged tissues ${ }^{(28)}$. visibility of dispersed dentin particles in $20 \%$ of cases and nearly $70 \%$ treated cases showed organized odontoblastic layer that may be due to odontoblasts stimulation effects of (3 mix). 
In this study, the pulp tissues in Allium sativum group showed mild inflammation after 15 and 30 days with mild to moderate pulpal fibrosis. Odontoblastic layer was intact and well organized in $73 \%$ of cases treated with Allium sativum ,this indicated that the pulp tissues in state of reversible pulpitis which will initiate recovery of any damaged pulp tissues that resulted from infection or pulp tissue trauma. Those findings were in agrenement with Mohammad and Baroudi ${ }^{(29)}$ who concluded that A. sattivum has favourable clinical results as pulpotomy material in primary molar that is due to anti- inflammatory and analgesic effects of it. These properties may be due to presence of ajoene and diallyl sulfide in A. sativum which inhibit prostaglandin ${ }^{(30)}$. Moreover, Mohammad et al. ${ }^{(31)}$, concluded that A. sativum oil compromises a good healing potential, that makes the residual pulp tissues healthy and functioning.

The histological finding of current study confirmed that there were promising outcomes of triantibiotic paste and A.sativum when comparing them as vital pulpotomy medicaments for primay teeth with formacresol which induced internal resorption and pulp necrosis to pulp tissues. In addition they induced mild inflammatory reactions on pulp that makes pulp tissue capable to repair.

\section{CONCLUSIONS}

1- Tri-antibiotic paste induced mild to moderate pulp inflammatory reactions compared to formacresol which induce sever inflammatory cells infilterations and pulp necrosis .

2- A.sativum induced mild pulp inflammatory reactions when compared with formacresol.

3- Odontoblast remained intact in most cases treated with Both Tri- antibiotic paste and A. sativum compared with formacresol.

4- Interal root resorption found in most specimens treated with formacresol compared to minimal amounts in tri-antibiotic paste and A. sativum treated groups.

\section{RECOMMENDATIONS}

1- Further clinical studies with long time evaluation periods should be done to investigate the effects of tri-antibiotic pastes on pulp of primary teeth to confirm its reparative effects on dental pulp.

2- Further clinical studies with long time evaluation periods should be done to investigate the effects of A. sativum on pulp tissues of primary teeth and to confirm its anti-inflammatoy reaction.

3- Tri-antibiotic paste and A.sativum can replace formacresol as a vital pulpotomy medication in the future.

\section{ACKNOWLEDGMENTS}

Thanks to all children and their parents who were participating in this study.

\section{REFERENCES}

1. Simancas-Pallares MA, Díaz-Caballero AJ, LunaRicardo LM. Mineral trioxide aggregate in primary teeth pulpotomy. A systematic literature review. Med. Oral Patol. Oral Cir. Bucal. 2010;15(6):e942-6.

2. Nadin G, Goel BR, Yeung CA, Glenny AM. Pulp treatment for extensive decay in primary teeth. Cochrane Database Syst. Rev. 2003;(1):CD003220.

3- Schmitt D, Lee J, Bogen G. Multifaceted use of ProRoot MTA root canal repair material. Pediatr Dent. 2001;23(4):326-30.

4. Loos PJ, Han SS. An enzyme histochemical study of the effect of various concentrations of formocresol on connective tissues. Oral Surg. Oral Med. Oral Pathol. 1971; 31:571-85

5. Schwartz RS, Mauger M, Clement DJ, Walker WA., 3rd Mineral trioxide aggregate: A new material for endodontics. J Am. Dent. Assoc. 1999;130:967-75.

6. Judd PL, Kenny DJ. Formocresol concerns. A review. J. Can. Dent. Assoc. 1987;53:401-4.

7. Myers DR, Shoaf HK, Dirksen TR, Pashley DH, Whitford GM, Reynolds KE. Distribution of 14C-formaldehyde after pulpotomy with formocresol. J. Am. Dent Assoc. 1978;96:805-13. 
8. Lewis BB, Chestner SB. Formaldehyde in dentistry: A review of mutagenic and carcinogenic potential. J. Am. Dent. Assoc. 1999;103:429-34.

9. Ranly DM, Horn D. Assessment of the systemic distribution and toxicity of formaldehyde following pulpotomy treatment: Part two. ASDC. J. Dent. Child. 1987;54:40-6.

10. Sun HW, Feigal RJ, Messer HH. Cytotoxicity of glutaraldehyde and formaldehyde in relation to time of exposure and concentration. Pediatr. Dent. 1990;12:303-7.

11. Haq A, Lopo PI, Al-Tufail M, Rama NR, Al-Sedairy ST. Immunomodulatory effect of Nigella sativa proteins fractioned by ion exchange chromatography. Int. J. Immunopharmacol. 1970;21:283-95.

12. Blania G, Spangenberg B. Formation of allicin from dried garlic (Allium sativum): A simple HPTLC method for simultaneous determination of allicin and ajoene in dried garlic and garlic preparations. Planta. Med. 1991; 57:371-5.

13. Chutima Trairatvorakul and Treesa Sastararuji . Indirect pulp treatment vs antibiotic sterilization of deep caries in mandibular primary molars. International Journal of Paediatric Dentistry. 2014; 24: 23-31.

14. Sato T, Hoshino E, Uematsu H, Noda T. In vitro antimicrobial susceptibility to combinations of drugs on bacteria from carious and endodontic lesions of human deciduous teeth. Oral Microbiol Immunol. 1993; 8: 172-6.

15. Hoshino E, Kurihara-Ando N, Sato I, Uematsu H, Sato M, Kota K, Iwaku M. In vitro antibacterial susceptibility of bacteria taken from infected root dentine to a mixture of ciprofloxacin, metronidazole and minocycline. Int. Endod. J. 1996; 29: 125-30.

16. Sato T, Hoshino E, Uematsu H, Kota K, Iwaku M, Noda T. Bactericidal efficacy of a mixture of ciprofloxacin, metronidazole, minocycline and rifampicin against bacteria of carious and endodontic lesions of human deciduous teeth in vitro. Microb. Ecol .Health Dis. 1992; 5: 171-7.

17. Tsao SM, Yin MC. In-vitro antimicrobial activity of four diallyl sulphides occurring naturally in garlic and Chinese leek oils. J. Med. Microbiol. 2001;50:646-9.

18. Martin KW, Ernst E. Herbal medicines for treatment of bacterial infections: A review of controlled clinical trials. J Antimicrob Chemother. 2003;51:241-6.

19. Fani MM, Kohanteb J, Dayaghi M. Inhibitory activity of garlic (Allium sativum) extract on multidrug-resistant Streptococcus mutans. J. Indian Soc. Pedod. Prev. Dent. 2007; 25:164-8.

20. Llewellyn BD. Nuclear staining with alumhematoxylin. Biotech. Histochem. 2009; 84: 159- 77.

20. Nakornchai S, Banditsing P, Visetratana N. Clinical evaluation of 3Mix and Vitapex as treatment options for pulpally involved primary molars. Int J Paediatr Dent. 2010; 20: 214-21.
21. Shukry Gamal Mohammad, Syed Ahmed Raheel, Kusai Baroudi. Clinical and Radiographic Evaluation of Allium sativum Oil as a New Medicament for Vital Pulp Treatment of Primary Teeth. Journal of International Oral Health. 2014; 6(6):32-6.

22. Pranitha Kakarla, JogendraSai Sankar Avula, George Manojkumar Mellela, Sujatha Bandi and Sampath Anche. Dental pulp response to collagen and pulpotec cement as pulpotomy agents in primary dentition:histopathological study. J.Conserv.Dent. 2013;5:434-8.

23. Sonia Sivadas, Arathi Rao, Srikant Natarajan, Ramya Shenoy, Suprabha Baranya Srikrishna. Pulpal Response to Ferric Sulfate and Diode Laser When Used as Pulpotomy Agent: An In vivo Study. Journal of Clinical and Diagnostic Research. 2017 ;11(6): ZC87-ZC91.

24. N Ratnakumari and Bijimol Thomas . A Histopathological Comparison of Pulpal Response to Chitra-CPC and Formocresol used as Pulpotomy Agents in Primary Teeth: A Clinical Trial. . International Journal of Clinical Pediatric Dentistry. 2012;5(1):6-13

25. Omar OM1, Khattab NM and Khater DS. Nigella sativa oil as a pulp medicament for pulpotomized teeth: a histopathological evaluation. J Clin Pediatr Dent.. 2012 ; 36(4):335-41.

26. Ranly DM. Pulpotomy therapy in primary teeth: new modalities for old rationales. Pediatr Dent. 1994;16:403-9.

27. El-Tawil SB, ElDokki NA, Aly ZH.Comparative evaluation of jojoba oil versus formacresol pulpotomy in primary molars.in vitro study. Pakistan oral dental j. 2009;29:85-92.

28. Divya Doneria, Seema Thakur, Parul Singhal, Deepak Chauhan. Comparitive evaluation of clinical and radiographical success of zinc oxide ozonated oil, modified 3 mix antibiotic -mp paste, and vitapex as treatement options in primary molars requiring pulpectomy: An in vitro study. Journal of Indian society of pedodontics and preventive dentistry 2017;35: 346-52.

29. Shukry Gamal Mohammad and Kusai Baroudi. Assessment of the potential of Allium sativum oil as a new medicament for non-vital pulpotomy of primary teeth. Journal of International Society of Preventive and Community Dentistry. 2015; 5(4):3-14

30. Hajhashemi V, Ghannadi A, Jafarabadi H. Black cumin seed essential oil, as a potent analgesic and antiinflammatory drug. Phytother. Res. 2004;18: 195-9. [PubMed]

31. El-Mahmoudy A, Matsuyama H, Borgan MA, Shimizu Y, ElSayed MG, Minamoto N, et al. Thymoquinone suppresses expression of inducible nitric oxide synthase in rat macrophages. Int Immunopharmacol. 2002;2:603-11. [PubMed] 